\title{
Печникова О.Г. \\ Институционализация медицинской деятельности: правовое закрепление основных принципов организации деятельности карантинной службы в России в XVIII - начале XIX вв. \\ ФБОУ ВО РГУ нефти и газа (нацииональный исследовательский университет) имени И.М. Губкина \\ (Россия, Москва)
}

doi:10.18411/spc-20-10-2017-08

idsp: 000001:spc-20-10-2017-08

\section{Аннотация}

В статье анализируется эволюция формирования общественной потребности в организации деятельности карантинной службы в России в XVIII - начале XIX вв., планомерное включение противоэпидемических мероприятий в ряд важнейших задач внутренней и внешней политики, в том числе, обусловливающих экономическое развитие государства и нашедших правовое закрепление в нормативных источниках, их определяющих и составляющих значительную часть процесса институционализации медицинской деятельности продолжающегося и в наше время.

Ключевые слова: проблемы теории и истории государства и права, нормативное регулирование карантинной службы в России, история и теория права, права человека и гражданина, институционализация медицинской деятельности.

\section{Abstract}

This article analyzes the evolution of the formation of public need in the organization of quarantine service in Russia in XVIII - the beginning of the XIX century, the systematic inclusion of anti-epidemic measures in a number of important problems of internal and foreign policy, including that determine the economic development of the country and have found legal consolidation in. regulatory sources, and their determinants which constitute a substantial part of the process of institutionalization of medical activity continued in our time.

Keywords: problems of theory and history of state and law, regulation quarantine service in Russia, history and theory of law, human and civil rights, institutionalization of medical activity.

Формирование общественной потребности в организации деятельности карантинной службы в России в XVIII - начале XIX вв. началось в более давние времена, с момента появления опустошающих эпидемий. Первую «крепкую заставу» рядом с местом, где «моровое поветрие было», в 1592 г. дислоцировало в городе Ржеве военное ведомство, вводя в ней апробированные в баталиях, принципы охраны военного объекта, куда входили, например, оцепление и охрана территории, ограничение транзита, предусматривалось применение жестоких санкций к нарушителям [1].

Основной целью первых карантинов было: задержать на несколько недель людей и товары, препятствуя попаданию инфекции в крупные города. Этот срок позволял выявить больных, проветрить или «предать огню» товары. Долгое время в организации карантинных мероприятий отсутствовало нормативно закрепленное обязательное участие медиков. Впервые их присутствие 24 октября 1718 г. нормативно закрепил Сенатский указ Петра I «O посылке из Аптекарского приказа в Старооскольскую и Белгородскую провинции лекарей для осмотрения на людях моровой язвы, об устроении на дорогах крепких застав и в удобных местах виселиц, дабы никто не проезжал, под смертною казнию» [2]. Ряд положений об организации карантинов обозначились в Морском Уставе от 13 января 1720 г. [3], а также в 
«Регламенте о Управлении Адмиралтейства и верфи и части второй Регламента Морскаго» от 5 апреля 1722 г. [4]. Далее, участие Российская империи в межгосударственных соглашениях проявилось в состоявшемся договоре между Россией, Швецией и Данией, согласно Именному указу от 15 мая 1739 г. «О даче паспортов кораблям, с прописанием о здоровом состоянии пассажиров» [5].

Оценивая финансовые потери, наносимые эпидемией и понимая экономическую выгоду, получаемую от большего вклада в производство здоровых людей, Екатерина II утвердила Именной указ от 5 сентября 1784 г. «Об учреждении застав в Иркутской губернии, для предосторожности от болезни»[6]. Принципы организации карантинной службы в Российской империи были систематизированы и изложены в Указе от 6 мая 1786 г. «Положения о карантинном доме на острове Сескаре» [7]. Имеющиеся в нем положения во многом соответствовали прежним законам, продолжавшим свое действие и переносились в последующие (например, в Именной указ данный Сенату от 28 апреля 1805 г. «О запрещении привознаго торгу старым платьем, обувью, бельем, постелями и всякими лоскутьями»[8]).

Утвержденным Павлом I Доклад Медицинской Коллегии «Об учреждении Медицинских Управ» от 19 января 1797 г. [9], на Управу, возлагалась не только работа, связанная с лечением больных, сбором данных о болезнях и санитарнопросветительские мероприятия. Становясь на передовой линии в борьбе с опасной инфекцией, Врачебная Управа оповещала Медицинскую Коллегию об идентифицированном заболевании, предоставляла данные статистики, служила источником для сбора и накопления данных по лечению и профилактике болезней с использованием имеющегося опыта и практических знаний губернских медиков. В местах скученности людей на промышленных предприятиях происходило увеличение заболеваемости, связанное с быстрым распространением высоко контактной инфекции. В связи с чем, собственные медики не могли справиться с лечением в условиях эпидемии. Медицинская Коллегия дополнительно командировала своих сотрудников на борьбу с болезнями. Так происходило, например, при устранении эпидемии «в окрестностях Колывановских заводов» [10].

В целях реализации государственной задачи по соблюдению «нужной осторожности, против моровой язвы», был принят «Устав пограничных и портовых карантинов, Всеподданнейший доклад от действительных тайных советников: государственного казначея барона Васильева, Коммерц-Коллегии президента князя Гагарина, вице-канцлера графа Панина и генерала от инфантерии и генерал - прокурора Обольянинова» от 7 июля 1800 г., (далее - Устав пограничных и портовых карантинов от 7 июля 1800 г.) [11]. Настоящий закон служил основой в формировании иного отношения к возможностям карантинной службы, позволяя «умножить государственный доход»: предоставлял возможность реализации обеззараженного товара и препятствия разорению хозяев корабля. Причиной разорения являлось добросовестное следование закону, обязывающему «предавать огню корабль и другое мореходное судно со всем грузом, на котором оказалась моровая язва». В противном случае запрещалось заходить в порт. «Ради собственного спасения, скрыв свое несчастье», владельцы кораблей зачастую пытались спрятать больных, изменяли название государства, откуда прибыли, производили попытки войти в другой порт.

Облегчить финансовое бремя государственных расходов, связанных с «искоренением моровой язвы», предполагалось за счет налогообложения экспорта и импорта: на «содержание столь полезного и необходимого заведения при всех портовых и пограничных таможнях и заставах повелено брать со всех товаров привозных по два, а отвозных по одному проценту, сверх таможенных доходов», вводилась также отдельная плата за дезинфекцию товара, например, «с шелку пряденого и сырцу» - по «8 рублей с каждого пуда». Этот тариф мог меняться, все полученные доходы полагалось направить в банк «для обращения тамо: под названием 
карантинной суммы, единственно в пользу сего заведения ..,, а когда от оных остатков соберется такой капитал, что одними процентами все сие учреждение содержаться в состоянии, то и вовсе таковой сбор, по усмотрению обстоятельств, отменен быть может».

Особую важность и государственное признание мер дезинфекции, подчеркивали, предусмотренные в законе, награды за труд карантинных чиновников. Устав портовых и пограничных карантинов от 7 июля 1800 г., предусматривал правила строения карантинного дома, называя организацию карантинов «при портах и на сухой границе», одним из «самых благонадежных средств, избавляющих государство от опасности, моровою язвою наносимой, которое споспешествует спокойствию и благосостоянию людей вообще». Прописывались необходимые требования, предусмотренные для строительства объекта, представляющего санитарноэпидемическую опасность: «местоположение открытое, возвышенное, лежащее близ моря или реки, по течению воды ниже близ лежащих к оному селений», вдали от болот и «от жилья не меньше версты».

Таким образом, длительно формировавшаяся общественная потребность в организации деятельности карантинной службы, стала отправной точкой для включения противоэпидемических мероприятий в ряд важнейших задач внутренней и внешней политики, что обрело правовое закрепление в нормативных источниках, их определяющих и составляющих значительную часть процесса институционализации медицинской деятельности, продолжающегося и в наше время.

\section{$* * *$}

1. Полное собрание законов Российской империи (далее ПСЗ РИ). Собр. 1. Т. V. № 3006. СПб., 1830.

2. ПСЗ РИ. Собр. 1. Т. IV. №. 3234. СПб., 1830.

3. ПСЗ РИ. Собр. 1. Т. VI. № 3485. СПб., 1830.

4. ПСЗ РИ. Собр. 1. Т. VІ. № 3937. СПб., 1830.

5. ПСЗ РИ. Собр. 1. Т. Х. № 7802. СПб., 1830.

6. ПСЗ РИ. Собр. 1. Т. ХХІІ. № 16050. СПб., 1830.

7. П ПСЗ РИ. Собр. 1. Т. ХХІІ. № 16390. СПб., 1830.

8. ПСЗ РИ. Собр. 1. Т. ХХVІІІ. № 21732. СПб., 1830.

9. ПСЗ РИ. Собр. 1. Т. ХХІV. № 17743. СПб., 1830.

10. Российский Государственный Архив древних актов (далее РГАДА). Ф. 344. Оп. 2. Кн. 16. Д. 6.

11. ПСЗ РИ. Собр. 1. Т. ХХУІ. № 19476. СПб., 1830.

\section{Стоякина О.B. \\ Особенности реализации избирательных прав молодежи на муниципальном уровне \\ ЧПОУ «Светлоградский многопрофильный колледж» (Россия, Светлоград)}

doi:10.18411/spc-20-10-2017-09

idsp: 000001:spc-20-10-2017-09

Право на управление делами государства как непосредственно, так и через своих представителей относится к конституционным правам граждан Российской Федерации. Конституция РФ в ч.2 ст. 32 прямо предусматривает право граждан Российской Федерации избирать и быть избранными в органы государственной власти и органы местного самоуправления, а также участвовать в референдуме.

На реализацию данного права направлен и Федеральный закон от 12.06.2002 N 67-Ф3 (ред. от 01.06.2017) «Об основных гарантиях избирательных прав и права на участие в референдуме граждан Российской Федерации» (с изм. и доп., вступ. в силу с 01.10.2017) [1], который в Главе IX предусматривает гарантии прав граждан при организации и осуществлении голосования, установлении итогов голосования, 